\title{
PENGARUH PENGGUNAAN MODEL COOPERATIVE LEARNING TIPE TAKE AND GIVE TERHADAP HASIL BELAJAR IPS TERPADU SISWA KELAS VIII SEMESTER GENAP SMP MUHAMMADIYAH 1 METRO TAHUN PELAJARAN 2016/2017
}

\author{
Arin Septiana ${ }^{1}$ Ningrum $^{2}$ \\ Pendidikan Ekonomi FKIP Universitas Muhammadiyah Metro \\ arin37499@gmail.com Nigrum34@yahoo.co.id ${ }^{2}$
}

\begin{abstract}
Abstrac
The learning process shouldbe supported by the interaction between students and teachers. Students who have no interest at the time of study should be given the solution, because it will impacts for low student in learning outcomes. One of the solutions is to improve less interesting learning processthat is by applying cooperative learning model take and give type. The problem formulation in this research "is there any influence of using cooperative learning model take and give type to wards the students' learning outcomes in Social Science at VIII Grade of SMP Muhammadiyah 1 Metro in even semester of 2016/2017?" The purpose of this study is to determine the effect of cooperative learning take and give typetowards the students' learning outcomes in Integrated Social Science at VIII Grade of SMP Muhammadiyah 1 Metro in even semester of 2016/2017?. Data collection techniques used in this study are observation, interview, documentation and test. Hypothesis in this study is "There is a positive influence of usingcooperative learning model take and give type to wards the students' learning outcomes in Integrated Social Science at VIII Grade of SMP Muhammadiyah 1 Metro in even semester of 2016/2017?. Population in this study is all students of VIII Grade, and the determination of the sample by using cluster random sampling selected to be the sample is class $\mathrm{VIII}_{\mathrm{B}}$ as an experimental class and class $\mathrm{VIII}_{\mathrm{C}}$ as a control class. Next, see from simple linear regression calculation can be known that the hypohtesis is received because $t_{\text {hit }}>t_{\text {tab }}$ can be seen at the real level $5 \%$ thet is $2,6589>1,70$ and on a real level $1 \%$ thet is $2,6589>2,47$. Therefore, there is a positive influence of usingcooperative learning model take and give type to wards the students' learning outcomes in Integrated Social Science at VIII Grade of SMP Muhammadiyah 1 Metro in even semester of 2016/2017.
\end{abstract}

Keywords: Cooperative Learning Model Take And Give Type And Integrated Social Scienceof Learning Outcomes

\section{PENDAHULUAN}

Belajar pada hakekatnya merupakan proses kegiatan secara berkelanjutan dalam rangka perubahan perilaku peserta didik secara konstrktif atau semua aktivitas mental atau psikis yang berlangsung dalam interaksi aktif dalam lingkungan, yang menghasilkan dalam perubahan-perubahan dalam pengelolahan pemahaman.

Tujuan pendidikan adalah membentuk sumber daya manusia yang berkualitas tinggi yaitu manusia yang mampu 
menghadapi perkembangan zaman. Keberhasilan suatu pendidikan salah satunya ditentukan oleh bagaimana proses pembelajaran itu berlangsung. Selain itu proses interaksi belajar pada prinsipnya tergantung pada guru dan siswa.

Guru adalah seorang pendidik. Pendidik adalah orang dewasa dengan segala kemampuan yang dimilikinya untuk dapat mengubah psikis dan pola pikir anak didiknya dari tidak tahu menjadi tahu serta mendewasakan anak didiknya. Salah satu hal yang harus dilakukan oleh guru adalah dengan mengajar di kelas. Bagaimana seorang guru dapat menguasai keadaan kelas sehingga tercipta suasana belajar yang menyenangkan.

Seorang guru yang krativ harus menggunakan model pembelajaran yang sesuai dengan karakteristik peserta didiknya. Tiap-tiap kelas bias menggunakan model pembelajaran yang berbeda dengan kelas lain. Untuk itu seorang guru harus mampu menerapkan berbagai model pembelajaran. Model pembelajaran mempunyai peran yang begitu penting, maka menerapkan model yang efektif dan efisien diharapan proses pembelajaran akan berjalan menyenangkan dan tidak membosankan.

Ketepatan dalam menyampaikan materi pembelajaran dengan model pembelajaran yang benar akan mempermudah dan mempercepat proses penyampaian ilmu kepada anak didik. Usaha-usaha yang dilakukan untuk menerapkan model pembelajaran yang tepat belum mencapai tujuan sesuai dengan yang diharapkan. Hal ini terbukti hasil belajar IPS Terpadu siswa masih rendah. Keberhasilan pendidikan di SMP Muhammadiyah 1 Metro merupakan harapan bagi setiap orang tua, pemerintah dan masyarakat pada umumnya.

Hasil prasurvei di SMP Muhammdiyah 1 Metro menunjukkan bahwa hasil belajar IPS Terpadu siswa masih banyak yang belum tuntas. Siswa yang belum tuntashasil belajarnya masih 18 siswa dan yang sudah tuntas hanya 12 siswa.

Tujuan penelitian ini adalah "untuk mengetahui pengaruh model Cooperative Learning tipe Teke and Give terhadap hasil belajar IPS Terpadu Semester Genap di SMP Muhammadiyah 1 Metro Tahun Pelajaran 2016/2017”

\section{KAJIAN PUSTAKA}

\section{Hasil Belajar}

Hasil belajar adalah suatu kemampuan siswa dalam mendapatkan suatu nilai atau perubahan dalam belajar. Menurut Keller (dalam Mulyono 2003:38) memandang hasil belajar sebagai keluaran dari suatu sistem pemrosesan berbagai masukan yang 
berupa informasi. Menurut Dimyati \& Mudjiono (2006:3) hasil belajar merupakan hasil dari suatu interaksi tindak belajar dan tindak mengajar.

Berdasarkan pendapat yang telah dipaparkan dapat disimpulkan bahwa hasil belajar adalah hasil yang telah dicapai siswa setelah mengikuti proses pembelajaran dan memenuhi suatu tahapan pencapaian dalam pengalaman belajar. Dalam hak ini yang peneliti akan ukur ialah hasil belajar yang hanya di lihat dari hasil belajar kognitif siswa.

Hasil belajar siswa dipengaruhi oleh beberapa faktor. Menurut Karwono (2012:47-50) yang menyebutkan bahwa faktor -faktor yang mempengaruhi hasil belajar yaitu :

1. Faktor internal yaitu faktor yang timbul dari siswa itu sendiri, faktor internal ini dapat diklasifikasikan menjadi dua yaitu:
a. Faktor fisiologis (jasmani) seperti: normal dan cacat, bentuk tubuh kuat atau lemah.
b. Faktor psikologis seperti: intelegensi, emosi, bakat, motivasi dan perhatian.

2. Faktor eksternal yaitu faktor yang timbul dari luar diri siswa atau sering disebut lingkungan. Lingkungan dapat diklasifikasikan kedalam berbagai bentuk antara lain: a. Faktor lingkungan sekitar, yang meliputi interaksi guru dan murid, cara penyajian bahan pelajaran, kurukulum, pelaksanaan disiplin, metode mengajar, tugas pokok.

b. Faktor lingkungan keluarga yang meliputi cara memdidik anak, suasanakeluarga, perhatian, keadaan sosial ekonomi, latar belakang, kebudayaan dan lainlain.

c. Faktor lingkungan masyarakat yang meliputi media masa, teman bergaul, cara hidup lingkungan.

Berdasarkan pendapat yang telah dipaparkan dapat disimpulkan bahwa faktor-faktor yang mempengaruhi hasil belajar sangat kompleks tetapi secara garis besar dapat dibedakan menjadi dua faktor yang berasal dari dalam diri siswa dan faktor yang berasal dari luar diri siswa. Faktor-faktor tersebut merubah diri individu yang berupa ingatan, pengetahuan, kemampuan berpikir terhadap sesuatau yang telah di pelajari, itu semua dapat mempengaruhi hasil belajar siswa.

Model pembelajaran cooperative merupakan suatu pembelajaran kelompok dengan gagasan untuk saling memotivasi antara anggotanya untuk saling membantu 
agar tercapinya suatu tujuan pembelajaran yang maksimal.

Menurut Solihatin (dalam Tukiran, 2015:56) “cooperative learning juga dapat di artikan sebagai suatu struktur tugas bersama dalam suasana kebersamaan di antara sesama anggota kelompok".

Pembelajaran cooperative menurut Nurulhayati (dalam Rusman, 2014:203) adalah strategi pembelajaran yang melibatkan partisipasi siswa dalam kelompok kecil untuk saling berinteraksi.

Beberapa pendapat yang telah dipaparkan dapat disimpulkan bahwa pembelajaran Cooperative adalah cara belajar dalam bentuk-bentuk kelompokkelompok kecil yang saling bekerjasama dan diarahkan oleh guru sebagai fasilitator untuk mencapai tujuan pembelajaran yang diharapkan.

Take and Give termasuk salah satu model pembelajaran kooperatif. Model pembelajaran ini dilakukan dengan sebuah kartu yang berisi sub-sub materi yang telah di terangkan oleh guru, dan siswa yang sudah mendapatakan kartu, siswa mencarai pasangannya dan saling menerima dan memberi informasi yang di dapat di dalam kartu tersebut.

Menurut Abdullah (2014:238) "model pembelajaran take and give merupakan model pembelajaran yang membutuhkan sebuah kartu dengan ukuran sekitar $(10 \mathrm{~cm}$
$X 15 \mathrm{~cm}$ ), sejumlah peserta didik atau sejumlah kelompok. Masing-masing kelompok atau peserta didik menerima kartu yang berbeda, namun masih terkait dengan tujuan pembelajaran".

Menurut Huda (2015:241) “istilah take and give sering diartikan 'saling memberi dan saling menerima'. Model pembelajaran take and give merupakan strategi pembelajaran yang didukung oleh penyajian data yang awali dengan pemberian kartu kepada siswa. Di dalam kartu, ada catatan yang harus dikuasai atau di hafal masing-masing siswa.kemudian mencari pasanagan untuk bertukar pengetahuan sesuai dengan apa yang di dapatnya di dalam kartu".

Dari beberapa pendapat di atas maka penulis mengambil kesimpulan bahwa penerapan model pembelajaran Cooperative Tipe Take and Give (memberi dan menerima) adalah strategi pembelajaran yang menyajikan menggunakan sebuah kartu yang berisi materi yang menuntut siswa harus mampu memahami materi yang telah di berikan, dan setelah itu masing-masing siswa mencari pasangan dan bertukar materi yang di dapatnya sehingga di harapakan peserta didik dapat menguasai lebih banyak materi pembelajan melalui peserta didik lain. 
Model pembelahar take and give mempunyai beberapa langkah yang harus di laksanakan. Menurut Abdullah (2014: 238-239) langkah-langkah model pembelajaran take and give sebagai berikut:

1) Guru menjelaskan materi untuk memantapkan penguasaan, masingmasing peserta didik di beri satu kartu yang memuat topik yang harus di pelajarai selama 5 menit

2) Semua peserta didik di suruh berdiri dan mencari pasangan untuk saling memebrikan informasi. Setiap peserta didik menulis nama pasangannya pada kartu.

3) Penyampainnya informasi di lakukan sampai tiap peserta dapat saling menerima dan memberi masingmasing (Take and Give)

4) Setelah penyampain informasi selesai di lakukan, guru mengumpulkan semua kartu dan melakukan evaluasi. Evaluasi penguasaan peserta didik di lakuakan dengan memberikan pertannyaan pada sejumlah peserta didik yang mendapatkan informasi berdasarkan catatan pada kartu.

Berdasarkan langkah-langkah diatas dapat di ambil kesimpulan bahwa dengan menggunakan model pembelajaran cooperative tipe take and give model pembelajaran yang menggunakan kartu memberikan pemahaman kepadakan siswa untuk lebih bertanggung jawab dengan apa yang di berikan oleh guru, sebelum mereka saling memberi siswa harus menghafal terlebih dahulu materi yang terdapat di dalam kartu, setelah itu siswa mencari pasangan dan saling memberikan informasi kepada teman tentang materi yang di dapat, jadi materi yang di dapat tidak hanyak dari seorang guru, tetapi dengan peserta didik lain. Dengan model cooperative tipe take and give ini peserta didik dapat meraih keberhasilan dalam belajar yaitu dengan hasil belajar yang meningkat, di samping itu juga dapat melatih peserta didik untuk berinteraksi, dan bekerja sama dengan baik.

Semua model cooperative mempunyai kelebihan dan kekurang termasuk model cooperative tipe take and give. Menurut Huda (2015:243) model take and give mempunyai kelebihan dan kekurangan sebagai berikut:

a. Kelebihan model cooperative tipe take and give

1) Dapat dimodifikasi sedemikian rupa sesuai dengan keinginan dan situasi pembelajaran

2) Melatih siswa untuk bekerja sama dan menghargai kemampuan orang lain 
3) Melatih siswa untuk berinteraksi secara baik dengan teman sekelas

4) Memperdalam dan memepertajam pengetahuan siswa melalui kartu yang di bagikan

5) Meningkatkan tangguang jawab siswa, sebab masing-masing siswa di bebani pertanggungjawaban atas kartunya masing-masing

b. Kekurangan model cooperative tipe take and give

1) Kesulitan untuk mendisiplinkan siswa dalam kelompok-kelompok

2) Tetidak sesuaian skill antara siswa yang memiliki kemampuan akademik yang baik dan siswa yang kurang memiliki kemampuan akademik

3) Kecebderungan terjadinya free riders dalam setiap kelompok, untamanya siswa-siswa yang akrab satu sama lain

Berdasarkan kelebihan dan kekurang yang telah dipaparkan dapatdisimpulkan bahwa model take and give dapat di gunakan dalam aktivitas belajar siswa di sekolah, materi-materi yang di peroleh juga tidak harus dari guru dari siswa lain pun bisa saling memberi informasi.

\section{METODE PENELITIAN}

Penelitian ini bersifat pengaruh, yang mengkaji pengaruh antara variabel independen dan dependen. Untuk mendapatkan data tentang pengaruh penggunaan model pembelajaran cooperative leraning tipe take and give terhadap hasil belajar IPS Terpadu. Dalam penelitian ini, rancangan yang digunakan dalam penelitian adalah menggunakan Pre-tes dan Pos-tes yang akan di berikan kepada kelas kontrol dan kelas eksperimen. Proses pembelajaran akan dilakukan 4 kali tatap muka, baik pada kelas eksperimen maupun kelas kontrol. Dalam penelitian ini populasi yang di ambil adalah seluruh siswa kelas VIII. Dengan menetapkan sampel mengunakan cluster random sampling dengan cara di acak, yang terpilih adalah kelas $\mathrm{VIII}_{\mathrm{B}}$ sebagai kelas eksperimen dan $\mathrm{VIII}_{\mathrm{c}}$ sebagai kelas kontrol.

Teknik pengunpulan data di lakukan dengan beberapa cara:

\section{a. Observasi}

Observasi merupakan penelitian yang dilakuakan secara langsung denagan objek yang akan diteliti.

\section{b. Wawancara}

Metode wawancara merupakan proses tanya jawab dalam penelitian yang berlangsung secara lisan dimana dua orang atau lebih bertatap muka 
mendengarkan secara langsung informasiatau keterangan

\section{c. Dokumentasi}

Dokumentasi adalah suatu teknik untuk memperoleh informasi dari bermacam-macam sumber tertulis dan dokumen yang ada pada responden atau hal-hal yang berhubungan dengan variabel penelitian

\section{d. Test}

Tes adalah serangkaian latihan atau pertanyaan yang digunakan untuk mengukur pengetahuan, keterampilan, intelegensi, kemampuan atau bakat yang dimiliki oleh individu maupun kelompok

\section{HASIL PENELITIAN}

Berdasarkan penelitian yang dilakukan oleh peneliti ada pengaruh yang positif penggunaan model pembelajaran cooperativ elearning tipe take and give terhadap hasil belajar IPS Terpadu siswa kelas VIII semester genap SMP Muhammadiyah 1 Metro Tahun Pelajaran 2016/2017.

Dapat dilihat dari 30 siswa yang diberikan perlakuan (Treatment) penggunaan model pembelajaran Cooperative Learning Tipe Take and Give, siswa yang hasil belajar IPS Terpadu Termasuk dalam kategori tuntas Sebanyak
25 siswa atau sebesar 83,33\%, sedangkan siswa yang hasil belajar IPS Terpadu termasuk dalam kategori belum tuntas sebanyak 5 siswa atau 16,67\%.

Pada pengujian dengan menggunakan rumus Regresi Linier Sederhana $\hat{\mathbf{Y}}=\boldsymbol{a}+$ bX. Sehingga di peroleh $\hat{Y}=50,18+0,4 X$. Kemudian dari analisis yang dilakukan maka terbukti bahwa ada pengaruh yang positif penggunaan model pembelajaran Cooperative Learning Tipe Take and Give terhadap hasil belajar IPS Terpadu pada kelas VIII $_{B}$ SMP Muhamamdiyah 1 Metro. Hal ini dibuktikan dengan penghitungan analisis data dapat diketahui bahwa nilai tersebut $t_{\text {hit }}>t_{\text {tab }}$, dan terlihat pada taraf signifikan $5 \%$ yaitu $2,5164>1,70$. Dan pada taraf signifikan $1 \%$ yaitu $2,5164>$ 2,4 dengan demikian maka hipotesisnya diterima.

\section{KESIMPULAN}

Dari penelitian tersebut dapat di simpulkan bahwa ada pengaruh positif penggunaan model pembelajaran cooperativ elearning tipe take and give terhadap hasil belajar IPS Terpadu siswa kelas VIII semester genap SMP Muhammadiyah 1 Metro Tahun Pelajaran 2016/2017.

Pada pengujian dengan menggunakan rumus Regresi Linier Sederhana $\hat{\mathbf{Y}}=\boldsymbol{a}+$ bX. Sehingga di peroleh $\hat{\mathbf{Y}}=50,18+0,4$ JURNAL PROMOSI | 82 
X. Kemudian dari analisis yang dilakukan maka terbukti bahwa ada pengaruh yang positif penggunaan model pembelajaran Cooperative Learning Tipe Take and Give terhadap hasil belajar IPS Terpadu pada

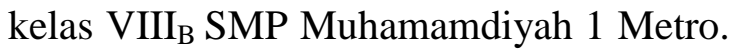
Hal ini dibuktikan dengan penghitungan analisis data dapat diketahui bahwa nilai tersebut $t_{\text {hit }}>t_{\text {tab }}$, dan terlihat pada taraf signifikan $5 \%$ yaitu $2,5164>1,70$. Dan pada taraf signifikan $1 \%$ yaitu $2,5164>$ 2,4 dengan demikian maka hipotesisnya diterima.

\section{DAFTAR PUSTAKA}

Abdullah Sani, Ridwan. 2014. Inovasi Pembelajaran. Jakarta: Bumi Aksara

Abdurrahman, Mulyono. 2003. Pendidikan Bagi Anak Berkesulitan Belajar. Jakarta: Rineka Cipta

Dimyanti, Mudjiono. 2006. Belajar dan Pembelajaran. Jakarta: Rineka Cipta

Huda Miftahul. 2015. Cooperative Learning (Metode, Teknik, Struktur Dan Model Penerapan). Yogyakarta: Pustaka Pelajar

Rusman. 2014. Model -Model Pembelajaran. Jakarta: Rajawali Pers
Taniredjo, Tukiran. 2015. Model-Model Pembelajaran Inovatif Dan Evektif. Bandung: Alfabeta 